\title{
GROWTH AND BIOMASS ALLOCATION OF THE C 4 GRASSES BRACHIARIA BRIZANTHA AND B. HUMIDICOLA UNDER SHADE ${ }^{1}$
}

\author{
MOACYRBERNARDINO DIAS-FILHO²
}

\begin{abstract}
The growth and biomass allocation responses of the tropical forage grasses Brachiaria brizantha $\mathrm{cv}$. Marandu and B. humidicola were compared for plants grown outdoors, in pots, in full sunlight and those shaded to $30 \%$ of full sunlight over a 30 -day period. The objective was to evaluate the acclimation capacity of these species to low light. Both species were able to quickly develop phenotypic adjustments in response to low light. Specific leaf area and leaf area ratio were higher for low-light plants during the entire experimental period. Low-light plants allocated significantly less biomass to root and more to leaf tissue than high-light plants. However, the biomass allocation pattern to culms was different for the two species under low light: it increased in B. brizantha, but decreased in $B$. humidicola, probably as a reflection of the growth habits of these species. Relative growth rate and tillering were higher in high-light plants. Leaf elongation rate was significantly increased on both species under low light; however, the difference between treatments was higher in B. brizantha. These results are discussed in relation to the pasture management implications.
\end{abstract}

Index terms: specific leaf area, growth rate, pastures, light regimes.

\author{
CRESCIMENTO E ALOCAÇÃO DE BIOMASSA NAS GRAMÍNEAS C \\ BRACHIARIA BRIZANTHA E B. HUMIDICOLA SOB SOMBREAMENTO
}

\begin{abstract}
RESUMO - O crescimento e a alocação de biomassa das gramíneas forrageiras tropicais Brachiaria brizantha cv. Marandu e B. humidicola foram comparados, em plantas cultivadas em vasos, a pleno sol e a $70 \%$ de interceptação da luz solar, durante um período de 30 dias. O objetivo foi avaliar a capacidade de aclimatação dessas espécies ao sombreamento. Ambas as espécies mostraram-se capazes de desenvolver rapidamente ajustes fenotípicos em resposta ao sombreamento. A área foliar específica e a razão de área foliar foram maiores durante todo o período experimental, nas plantas cultivadas à sombra. As plantas sombreadas alocaram significativamente menos biomassa nas raízes e mais nas folhas do que as plantas cultivadas à sombra. No entanto, a alocação de biomassa no colmo foi diferenciada entre as duas espécies sob sombreamento: aumentou em B. brizantha, mas diminuiu em B. humidicola, provavelmente como consequiência do hábito de crescimento dessas espécies. A taxa de crescimento relativo e o perfilhamento foram maiores nas plantas a pleno sol. A taxa de elongação foliar foi significativamente aumentada sob sombreamento em ambas as espécies; no entanto, a diferença entre tratamentos foi maior em $B$. brizantha. Esses resultados são discutidos com relação às suas implicações para o manejo.
\end{abstract}

Termos para indexação: área foliar específica, taxa de crescimento, pastagens, regime de luz.

\section{INTRODUCTION}

Most plants have the ability to adjust their morphological and physiological characteristics in

\footnotetext{
${ }^{1}$ Accepted for publication on August 31, 2000.

${ }^{2}$ Agronomist, Ph.D., Embrapa-Centro de Pesquisa Agroflorestal da Amazônia Oriental, Caixa Postal 48, CEP 66017-970 Belém PA, Brazil. CNPq Fellow.

E-mail: moacyr@cpatu.embrapa.br
}

response to exposure to unfavorable light environment (Pearcy, 1999). However, depending on their acclimation capacity, the efficiency of these adjustments can vary considerably among species. This acclimation capacity is key in determining their competitive potential in that specific environment (Gloser \& Gloser, 1996; Wong \& Stur, 1996; Dias-Filho, 1999; Nandal et al., 1999). 
Forage grasses in tropical pastures can be subjected to a considerable reduction in the amount of light they receive (Humphreys, 1991). This condition is usually a consequence of the deliberate introduction of tree species, or the invasion of woody weeds in active pasture areas, the establishment of pastures in plantations, or even the diurnal or seasonal reduction in the amount of sunshine due to cloud cover. In Brazil, shading of pasture areas by plantation agriculture has the potential to become more prevalent, since tree planting is being recommended as an alternative to reclaim degraded pasture areas (Carvalho, 1998; Dias-Filho, 1998). On the other hand, cloud cover can also greatly affect the amount of light pasture plants receive, particularly in the humid tropics. For example, in the North of Brazil $\left(1^{\circ} 28^{\prime} \mathrm{S}\right)$, a reduction of $60 \%$ in the daily mean sunshine duration, during the wet season (Dec to Apr), relative to the dry season (May to Nov), has been calculated for a three-year period.

Throughout tropical America, and particularly in Brazil, Brachiaria brizantha (Hochst. ex A. Rich.) Stapf cv. Marandu and B. humidicola (Rendle) Schweick are important forage grass species (Argel $\&$ Keller-Grein, 1996). Both have been classified as species with a medium tolerance to shade (Shelton et al., 1987; Humphreys, 1991). However, there is no comparative study examining the physiological and morphological responses of these species to a lowlight environment. The knowledge of these responses is critical to determine the acclimation capacity of these species to that specific environmental condition and to identify plant traits potentially important for successful competition under reduced light levels.

The aim of this study was to evaluate the acclimation capacity (phenotypic adjustment) of $B$. brizantha and B. humidicola to reduced light environment.

\section{MATERIAL AND METHODS}

\section{Plant material and growing conditions}

Seeds of Brachiaria brizantha cv. Marandu, and $B$. humidicola were germinated on sand and then planted individually in pots with $3.5 \mathrm{~kg}$ (dry mass) of soil (2:1; organic soil to sand). Pots were fertilized with a water soluble fertilizer solution of $48 \mathrm{ppm}$ of $\mathrm{P}\left(\mathrm{K}_{2} \mathrm{HPO}_{4}\right)$ and
$50 \mathrm{ppm}$ of $\mathrm{N}, 25 \mathrm{ppm}$ of K, $10 \mathrm{ppm}$ of S, $2 \mathrm{ppm}$ of $\mathrm{Zn}$, $1 \mathrm{ppm}$ of $\mathrm{Cu}, 0.5 \mathrm{ppm}$ of $\mathrm{B}$ and $0.2 \mathrm{ppm}$ of Mo. All plants were grown outdoors, under a black polypropylene shade fabric. Light extinction by the shade fabric measured with a Li-Cor quantum sensor (Li-Cor, Inc., Lincoln, NE, USA) on a clear day was $70 \%$. Ten days after planting, half of the pots were moved out of the shade fabric (full sun) and the other half stayed under the permanent shaded conditions. The light extinction value in the shade treatment is similar to that encountered under the canopy of most tree species in pastures in the region. Plants received ample water and were fertilized once a week with $50 \mathrm{~mL}$ of a water soluble fertilizer solution per pot (15:30:15; $\mathrm{N}, \mathrm{P}_{2} \mathrm{O}_{5}$, $\left.\mathrm{K}_{2} \mathrm{O} ; 3.5 \mathrm{~g} \mathrm{~L}^{-1}\right)$.

\section{Growth analysis}

Four harvests were made; the first harvest was on the day the treatments were imposed (ca. 18 days after germination), and the others 10,20 and 30 days later ( $n=4$ per harvest and treatment). At each harvest, plant material was divided into leaf blades, culms (sheath and stem) and roots. Leaf blades were removed and their areas were measured using a leaf area meter (LI-3000, with conveyor belt assembly, LI-3050; Li-Cor, Inc., Lincoln, NE, USA). Roots were washed free of soil using a manually manipulated jet spray of water. Plant dry mass was obtained by drying the plant material at $65^{\circ} \mathrm{C}$ for 48 hours. At each harvest, the specific leaf area (ratio between total leaf area per plant and total leaf dry mass per plant, SLA), leaf area ratio (ratio between total leaf area per plant and total dry mass per plant, LAR) and leaf, culm and root mass ratios (respectively, the ratio between leaf, culm, and root dry mass per plant and total dry mass per plant, LMR, CMR and RMR) were calculated. Relative growth rate (change in total dry mass per total dry mass of plant per day, RGR) was also calculated for each harvest interval. All of the above growth and biomass allocation parameters were calculated according to Hunt (1990) and the units were expressed according to Bugbee (1996).

\section{Leaf elongation rate}

The length of a young expanding leaf blade (with the ligule not yet exposed) of a vegetative tiller of each plant was measured with a ruler at around the same time every day. Leaves being measured were marked with a plastic ring. Once the ligule was exposed, a new leaf, on the same plant, was marked and measured. Daily leaf elongation was calculated as the difference between leaf lengths of two consecutive days. 


\section{Experimental design and statistical analysis}

The pots were arranged in a completely randomized design with four replications. For the leaf elongation measurements, three replications were used. Differences in biomass allocation, above ground biomass production, SLA and LAR throughout the experimental period were assessed by two-way ANOVA with treatments and evaluation dates as main effects. Differences in leaf elongation rate were assessed by three-way ANOVA with treatments, species and days as main effects. The assumption of homogeneity of variances and normality were tested for each ANOVA and, when necessary, data were log transformed. Transformed values were back transformed for presentation. Post hoc contrasts were calculated for assessing differences between treatments or within days and between treatments whenever appropriate.

Differences in RGR were tested as a treatment $x$ time interaction in an analysis of variance with logarithmicallytransformed dry mass as dependent variable (Poorter \& Lewis, 1986). A trend analysis over time was performed to detect differences in RGR throughout the experiment. Transformed data were back transformed for presentation.

The statistical package STATISTICA for Windows release 5.5 (StatSoft, Inc., Tulsa, USA) was used for all computations of the data.

\section{RESULTS AND DISCUSSION}

\section{Biomass allocation}

Fig. 1 shows the biomass allocation patterns throughout the experimental period. For both species, shading significantly reduced biomass allocation to roots $\left(\mathrm{F}_{1,24}=19.7 ; \mathrm{P}<0.001\right)$, and increased biomass allocation to leaves $\left(\mathrm{F}_{1,24}=35.7 ; \mathrm{P}<0.001\right)$. This shift in biomass allocation, favoring aboveground structures in detriment of roots, is a common response to shade in grasses and broad leaf species (Allard et al., 1991; Kephart et al., 1992; Paez et al., 1994; Dias-Filho et al., 1996; Cruz, 1997; Dias-Filho, 1997, 1999; Hodge et al., 1997), and it is intended to increase light harvesting capacity under low light. However, there was a differential allocation pattern to culms in response to shade - as expected, it was increased $\left(\mathrm{F}_{1,24}=6.58 ; \mathrm{P}<0.017\right)$ in $B$. brizantha, but, interestingly, it decreased $\left(\mathrm{F}_{1,24}=122 ; \mathrm{P}<0.001\right)$ in B. humidicola. This divergent response was probably a reflection of growth habits - erect in $B$. brizantha and prostrate in $B$. humidicola. The use of assimilates, during plant establishment, in high light $B$. humidicola, was mainly directed to "horizontal colonization" of ground space, which in a prostrate grass species means a preferential carbon allocation to stolons. In the erect $B$. brizantha, no such "horizontal colonization" exists, so, under high light, assimilates are mainly directed to roots and leaves. Under low light, increase in height (etiolation) as a light seeking strategy is expected. This would mean a proportionally higher investment in culms in the erect $B$. brizantha, when compared to the prostrate $B$. humidicola.

Mean values for the entire experiment showed that shade caused a significant increase in SLA and LAR on both species (Table 1). Under conditions of extreme shade, the preservation of high SLA and LAR is considered a key feature for growth maintenance (Gloser \& Gloser, 1996; Carlen et al., 1999) because it maximizes light capture. In tropical grasses, a high

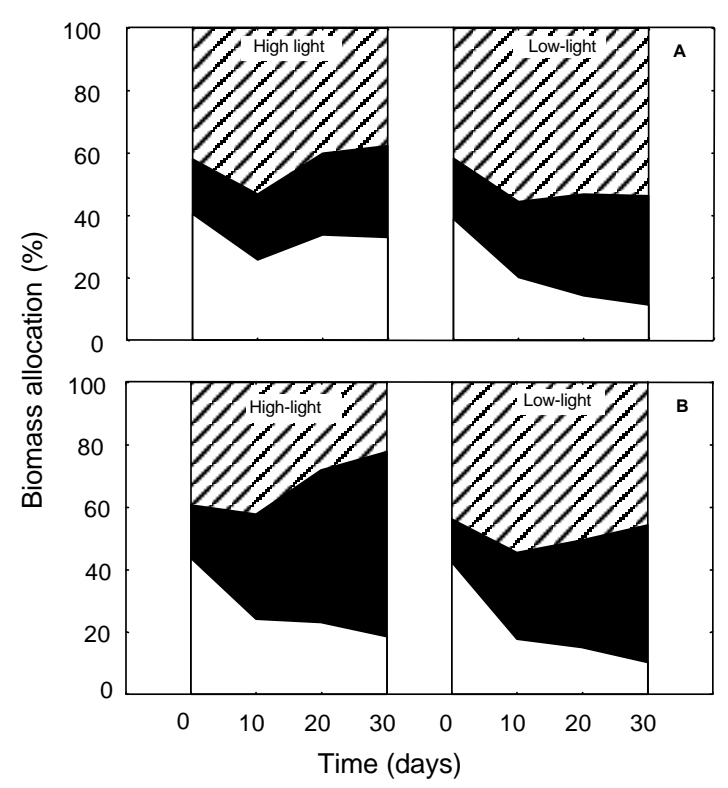

FIG. 1. Mean fraction of biomass allocated to roots (blank area), culms (dark area) and leaves (hatched area) as a function of time and light environment in Brachiaria brizantha (A) and Brachiaria humidicola (B). 
TABLE 1. Specific leaf area (SLA, $\mathbf{m}^{2} \mathbf{k g}^{-1}$ ), leaf area ratio (LAR, $\mathrm{m}^{2} \mathrm{~kg}^{-1}$ ) and number of tillers, as means for the entire experiment, of Brachiaria brizantha and $B$. humidicola under high- and low-light regimes. Values are means $( \pm$ s.d.), $\mathrm{n}=16$.

\begin{tabular}{|c|c|c|}
\hline Parameter & High-light & Low-light \\
\hline & \multicolumn{2}{|c|}{ Brachiaria brizantha } \\
\hline SLA & $21.90(8.7)$ & $29.50(10.6)$ \\
\hline LAR & $8.72(1.5)$ & $11.68(1.3)$ \\
\hline Tiller & $7.00(5.0)$ & $2.30(1.7)$ \\
\hline & \multicolumn{2}{|c|}{ Brachiaria humidicola } \\
\hline SLA & $27.00(9.9)$ & $31.90(10.4)$ \\
\hline LAR & $8.05(1.4)$ & $14.76(1.3)$ \\
\hline Tiller & $11.30(8.7)$ & $3.40(2.9)$ \\
\hline
\end{tabular}

SLA has been shown to improve interspecific competitive ability, but mainly in situations of relatively high soil fertility (Baruch et al., 1985). It has also been shown, for a group of $\mathrm{C}_{3}$ and $\mathrm{C}_{4}$ grasses subjected to shading, that there is a significant positive correlation between SLA and in vitro organic matter digestibility and $\mathrm{N}$ content in leaf blades, and a negative correlation between SLA and cell-wall lignin and neutral-detergent fiber (Kephart \& Buxton, 1993). So, although forage quality has not been evaluated in the present experiment, it possibly followed a similar trend.

\section{Growth}

For each species, the ANOVA for RGR produced a significant time $x$ treatment interaction, indicating a significant difference in the RGR between the treatments. Since most of the sum of squares treatment in each ANOVA was due to the linear component, it was concluded that the difference in RGR was maintained throughout the whole period examined (Fig. 2).

Traits usually associated with the maximization of RGR, like a higher SLA, LAR and LMR (Poorter \& Granier, 1999) were found in plants from the shade treatment, yet, RGR was significantly depressed by shade. However, shaded plants were able to maintain a positive RGR throughout the experimental period (Fig. 2). Both species responded similarly to shading.

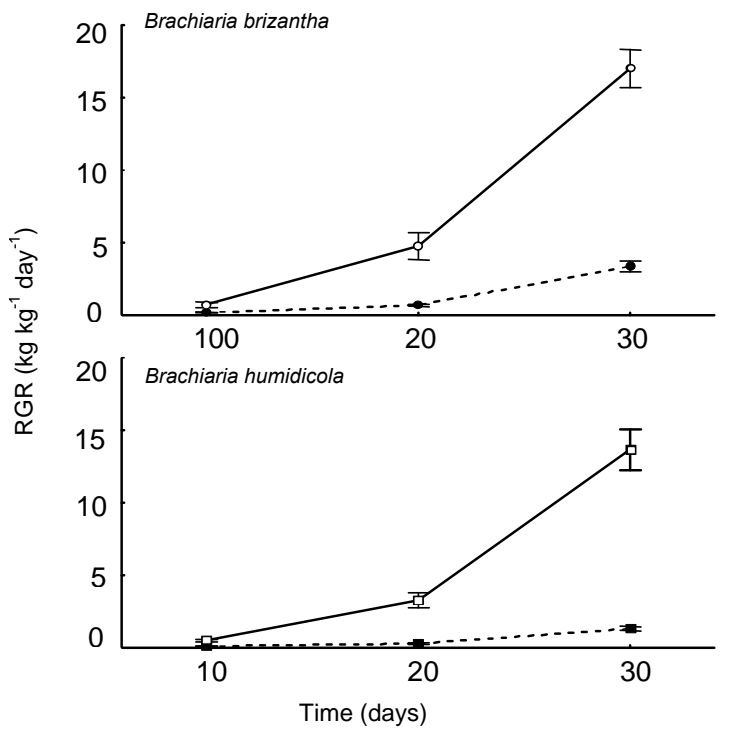

FIG. 2. Change over time in relative growth rates (RGR) (mean \pm s.e., $n=4$ ) of Brachiaria brizantha and Brachiaria humidicola under low- (closed symbols and dashed lines) and high-light (open symbols and solid lines) regimes.

Mean aboveground (leaves and culms) dry mass production of low-light plants was depressed by $74 \%$ $\left(\mathrm{F}_{1,24}=110.7 ; \mathrm{P}<0.001\right)$ in $B$. humidicola and by $75 \%$ $\left(\mathrm{F}_{1,24}=118.8 ; \mathrm{P}<0.001\right)$ in B. brizantha, while the relative reduction in root dry mass, caused by shade, was above $90 \%$ for both species. Development in low light also had a significant $(\mathrm{P}<0.001)$ negative effect on tillering, causing a mean reduction over time of $70 \%$ in B. humidicola and $67 \%$ in B. brizantha (Table 1). Results of a field trial in which $B$. brizantha was sown under a plantation, at an irradiance level of 30 to $40 \%$ of full sunlight, showed that the aboveground production, five months after sowing, was reduced by $51 \%$ relative to plants at full sunlight (Carvalho et al., 1995).

Since belowground biomass is reduced under shade, and because regrowth after defoliation depends to a large extent on remobilization of reserves stored in the belowground biomass (MorvanBertrand et al., 1999; Skinner et al., 1999; Nygren 
et al., 2000), it could be speculated that shaded plants would be more susceptible to stresses that cause loss of aboveground biomass, like herbivory or burning, than plants growing at full sunlight. Also, reduction in root growth might reduce the ability of a defoliated plant to regrow since both water and nutrient uptake would also be reduced. These should be considered when managing pastures of these species cultivated under low light.

\section{Leaf elongation rate}

A significant species $x$ treatment interaction was detected for leaf elongation rate $\left(\mathrm{F}_{2,372}=32.6 ; \mathrm{P}<0.001\right)$ (Fig. 3). Differences between treatments, within the same species, assessed by post hoc contrasts, indicated that the mean leaf elongation for the entire

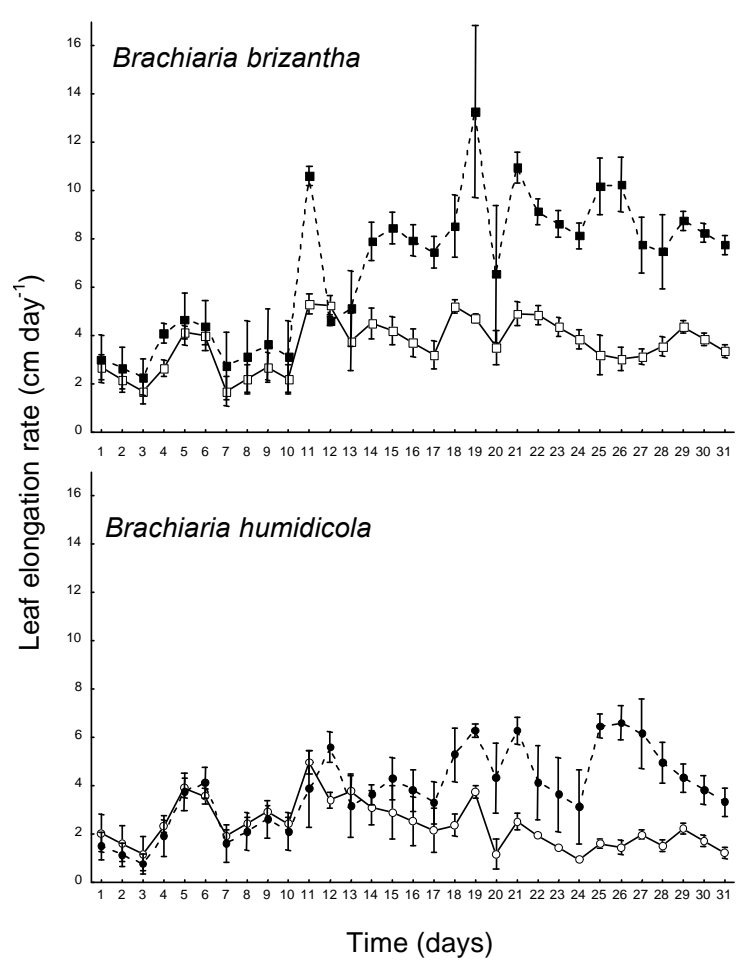

FIG. 3. Leaf elongation rate of Brachiaria brizantha and Brachiaria humidicola under low- (closed symbols, dashed line) and high-light (open symbols, solid line) regimes. Each point represents the mean \pm s.e. $(n=3)$. experiment was significantly increased by shade in B. humidicola $\left(\mathrm{F}_{1,372}=44.2 ; \mathrm{P}<0.001\right)$ and in B. brizantha $\left(\mathrm{F}_{1,372}=216.9 ; \mathrm{P}<0.001\right)$. Although shade promoted an increment in the overall leaf elongation rate of both species, the difference between treatments was higher in B. brizantha (Fig. 3), suggesting a relatively higher plasticity of this species to shading. B. brizantha also had mean leaf elongation rate values significantly higher (accessed by Tukey HSD test) than that of $B$. humidicola under both high $\left(3.61 \times 2.36 \mathrm{~cm} \mathrm{day}^{-1}\right)$ and low light $(6.82 \mathrm{x}$ $\left.3.81 \mathrm{~cm} \mathrm{day}^{-1}\right)$ conditions. These can be viewed as a feature related to this species more vigorous growth rate, when compared to $B$. humidicola (Fig. 2).

\section{CONCLUSIONS}

1. Both B. brizantha and B. humidicola quickly develop phenotypic adjustments as buffering mechanisms against light limitation and, as a consequence, are able to maintain growth to satisfactory levels under this condition.

2. Because on both species, allocation to root biomass, relative to aboveground biomass, is highly reduced under shade, they might become more vulnerable to stresses that depend heavily on root interference for recovery, such as drought stress, herbivore or burning.

\section{ACKNOWLEDGEMENTS}

To the former undergraduate PIBIC/CNPq fellows Aloisio F. Chagas Júnior and Michela C. Jaques Belarmino for their skilful technical assistance during the experiment evaluation.

\section{REFERENCES}

ALLARD, G.; NELSON, C.J.; PALLARDY, S.G. Shade effects on growth of tall fescue. I. Leaf anatomy and dry matter partitioning. Crop Science, Madison, v.31, p.163-167, 1991.

ARGEL, P.J.; KELLER-GREIN,G. Regional experience with Brachiaria: Tropical America humid lowlands. In: MILES, J.W.; MAASS, B.L.; VALLE, C.B. do (Ed.). Brachiaria: biology, agronomy, and 
improvement. Cali : Centro Internacional de Agricultura Tropical, 1996. p.205-221.

BARUCH, Z.; LUDLOW, M.M.; DAVIS, R. Photosynthetic responses of native and introduced $\mathrm{C}_{4}$ grasses from Venezuelan savannas. Oecologia, Berlin, v.67, p.388-393, 1985.

BUGBEE, B.G. Growth analysis and yield components. In: SALISBURY, F.B. (Ed.). Units symbols, and terminology for plant physiology: a reference for presentation of research results in the plant science. New York : Oxford University Press, 1996. p.115119.

CARLEN, C.; KOLLIKER, R.; NOSBERGER, J. Dry matter allocation and nitrogen productivity explain growth responses to photoperiod and temperature in forage grasses. Oecologia, Berlin, v.121, p.441446, 1999.

CARVALHO, M.M. Recuperação de pastagens degradadas em áreas de relevo acidentado. In: DIAS, L.E.; MELLO, J.W.V. (Ed.). Recuperação de áreas degradadas. Viçosa : UFV/Sociedade Brasileira de Recuperação de Áreas Degradadas, 1998. p.149-161.

CARVALHO, M.M.; FREITAS, V. de P.; ANDRADE, A.C. Crescimento inicial de cinco gramíneas tropicais em um sub-bosque de angico-vermelho (Anadenanthera macrocarpa Benth.). Pasturas Tropicales, Cali, v.17, p.24-30, 1995.

CRUZ, P. Effect of shade on the carbon and nitrogen allocation in a perennial tropical grass, Dichanthium aristatum. Journal of Experimental Botany, Oxford, v.48, p.15-24, 1997.

DIAS-FILHO, M.B. Pastagens cultivadas na Amazônia oriental brasileira: processos e causas de degradação e estratégias de recuperação. In: DIAS, L.E.; MELLO, J.W.V. (Ed.). Recuperação de áreas degradadas. Viçosa : UFV/Sociedade Brasileira de Recuperação de Áreas Degradadas, 1998. p.135-147.

DIAS-FILHO, M.B. Physiological response of Solanum crinitum Lam. to contrasting light environments. Pesquisa Agropecuária Brasileira, Brasília, v.32, n.8, p.789-796, ago. 1997.

DIAS-FILHO, M.B. Physiological responses of two tropical weeds to shade. I. Growth and biomass allocation. Pesquisa Agropecuária Brasileira, Brasília, v.34, n.6, p.945-952, jun. 1999.

DIAS-FILHO, M.B.; CHAGAS JÚNIOR, A.F.; CARVALHO, C.J.R. de. Respostas morfológicas e fisi- ológicas de Panicum maximum a diferentes condições de luminosidade. In: REUNIÃO ANUAL DA SOCIEDADE BRASILEIRA DE ZOOTECNIA, 33., 1996, Fortaleza. Anais. Fortaleza : Sociedade Brasileira de Zootecnia, 1996. p.62-64.

GLOSER, V.; GLOSER, J. Acclimation capability of Calamagrostis epigejos and C. arundinacea to changes in radiation environment. Photosynthetica, Prague, v.32, p.202-212, 1996.

HODGE, A.; PATERSON, E.; THORNTON, B.; MILLARD, P.; KILLHAM, K. Effects of photon flux density on carbon partitioning and rhizosphere carbon flow of Lolium perenne. Journal of Experimental Botany, Oxford, v.48, p.1797-1805, 1997.

HUMPHREYS, L.R. Tropical pasture utilization. Cambridge, Great Britain : Cambridge University Press, 1991. 206p.

HUNT, R. Basic growth analysis: plant growth analysis for beginners. London : U. Hyman, 1990. 112p.

KEPHART, K.D.; BUXTON, D.R. Forage quality responses of $\mathrm{C}_{3}$ and $\mathrm{C}_{4}$ perennial grasses to shade. Crop Science, Madison, v.33, p.831-837, 1993.

KEPHART, K.D.; BUXTON, D.R.; TAYLOR, S.E. Growth of $\mathrm{C}_{3}$ and $\mathrm{C}_{4}$ perennial grasses in reduced irradiance. Crop Science, Madison, v.32, p.10331038, 1992.

MORVAN-BERTRAND, A.; PAVIS, N.; BOUCAUD, J.; PRUD'HOMME, M.P. Partitioning of reserve and newly assimilated carbon in roots and leaf tissues of Lolium perenne during regrowth after defoliation: assessment by C-13 steady-state labeling and carbohydrate analysis. Plant Cell and Environment, Oxford, v.22, p.1097-1108, 1999.

NANDAL, D.P.; RANA, P.; KUMAR, A. Growth and yield of wheat (Triticum aestivum) under different tree spacings of Dalbergia sissoo based agrisilviculture. Indian Journal of Agronomy, New Delhi, v.44, p.256-260, 1999.

NYGREN, P.; VAILLANT, V.; DESFONTAINES, L.; CRUZ, P.; DOMENACH, A.M. Effects of nitrogen source and defoliation on growth and biological dinitrogen fixation of Gliricidia sepium seedlings. Tree Physiology, Victoria, v.20, p.33-40, 2000.

PAEZ, A.; GONZALEZ, M.E.; PEREIRA, N. Comportamiento de Panicum maximum en condiciones de sombreado y de luz solar total. Efecto 
de la intensidad de corte. Universidad del Zulia. Facultad de Agronomía. Revista, Maracaibo, v.11, p.25-42, 1994.

PEARCY, R.W. Responses of plants to heterogeneous light environments. In: PUGNAIRE, F.I.; VALLADARES, F. (Ed.). Handbook of functional plant ecology. New York : M. Dekker, 1999. p.269-314.

POORTER, H.; GRANIER, E. Ecological significance of inherent variation in relative growth rate and its components. In: PUGNAIRE, F.I.; VALLADARES, F. (Ed.). Handbook of functional plant ecology. New York : M. Dekker, 1999. p.81-120.

POORTER, H.; LEWIS, C. Testing the differences in relative growth rate: A method avoiding curve fitting and pairing. Physiologia Plantarum, Copenhagen, v.67, p.223-226, 1986.

SHELTON, H.M.; HUMPHREYS, L.R.; BATELLO, C. Pastures in the plantations of Asia and the Pacific: performance and prospect. Tropical Grasslands, St. Lucia, v.21, p.159-168, 1987.

SKINNER, R.H.; MORGAN, J.A.; HANSON, J.D. Carbon and nitrogen reserve remobilization following defoliation: Nitrogen and elevated $\mathrm{CO}_{2}$ effects. Crop Science, Madison, v.39, p.1749-1756, 1999.

WONG, C.C.; STUR, W.W. Persistence of tropical forage grasses in shaded environments. Journal of Agricultural Science, Cambridge, Great Britain, v.126, p.151-159, 1996. 